\title{
Variability and spatial correlation of soil micronutrients and organic matter with macadamia nut production
}

\author{
Jaqueline O. Paris ${ }^{1}$, Ivoney Gontijo ${ }^{2}$, Fábio L. Partelli ${ }^{2}$ \& Alexandro G. Facco ${ }^{2}$ \\ ${ }^{1}$ Universidade Federal do Espírito Santo/Programa de Pós-Graduação em Agricultura Tropical. São Mateus, ES, Brasil. E-mail: jack_orlandi@hotmail.com \\ (Corresponding author) - ORCID: 0000-0002-8801-8146 \\ ${ }^{2}$ Universidade Federal do Espírito Santo/Departamento de Ciências Agrárias e Biológicas. São Mateus, ES, Brasil. E-mail: ivoney.gontijo@ufes.br - ORCID: \\ 0000-0002-4251-4689; partelli@yahoo.com.br - ORCID: 0000-0002-8830-0846; agfacco@gmail.com - ORCID: 0000-0001-5496-1622
}

\begin{abstract}
Soil fertility is the key to agricultural production. The spatial correlation and location of nutrients may significantly affect the yields. The objective of this work was to evaluate the variability and spatial correlation of iron $(\mathrm{Fe})$, copper $(\mathrm{Cu})$, manganese $(\mathrm{Mn})$, zinc $(\mathrm{Zn})$, and organic matter $(\mathrm{OM})$ with macadamia nut yield. The study was conducted in an Oxisol cultivated for 20 years with macadamia nut in São Mateus, state of Espírito Santo, Brazil. A 100 point grid was used comprising an area of $144 \times 140 \mathrm{~m}$ with a minimum distance between points of $5 \mathrm{~m}$, in which a single composite soil sample was collected from 0-0.20 m layer for chemical analysis of $\mathrm{Fe}, \mathrm{Cu}, \mathrm{Mn}, \mathrm{Zn}$ and $\mathrm{OM}$. Nuts under the canopy's projection were harvested from February to June, 2015. The data were evaluated by geostatistical analysis using semivariograms, and kriging was used to map spatial distributions of nutrients and nut yield. All evaluated attributes showed strong or moderate spatial dependence structure. The OM was correlated positively with micronutrients, but only $\mathrm{Zn}$ was positively correlated with nut yield. Crossed semivariograms adequately explained the maps of $\mathrm{Zn}$ and $\mathrm{Mn}$; and Fe showed opposite tendency for macadamia nut yield.
\end{abstract}

Key words: Macadamia integrifolia, spatial variability, geostatistics, plant nutrition

\section{Variabilidade e correlação espacial de matéria orgânica e micronutrientes do solo com produtividade da macadâmia}

RESUMO: A fertilidade do solo é um fator decisivo para o rendimento das culturas agrícolas e a sua distribuição e correlação espacial, e podem alterar significativamente a produtividade média em uma área cultivada. Objetivou-se no presente trabalho estudar a variabilidade e correlação espacial dos micronutrientes ferro $(\mathrm{Fe})$, cobre $(\mathrm{Cu})$, manganês $(\mathrm{Mn})$, zinco $(\mathrm{Zn})$, da matéria orgânica $(\mathrm{MO})$ e da produtividade em uma área cultivada com macadâmia. O estudo foi desenvolvido em um Latossolo Amarelo distrocoeso, cultivado há 20 anos com macadâmia no município de São Mateus, ES. A malha instalada foi de 144 x 140 m com 100 pontos e com distância mínima de $5 \mathrm{~m}$, onde foi coletada uma amostra composta de solo na profundidade de 0-0,20 m, utilizada para análise química do $\mathrm{Fe}, \mathrm{Cu}, \mathrm{Mn}, \mathrm{Zn}$ e da MO. A colheita da macadâmia foi realizada no período de fevereiro a junho de 2015 , colhendo-se os frutos na projeção da copa da planta. Os dados foram submetidos à análise geoestatística através do ajuste de semivariogramas experimentais e o método de krigagem foi aplicado para mapear os padrões espaciais dos nutrientes e da produtividade. Todos os atributos em estudo apresentaram estrutura de dependência espacial (forte e moderada). A MO teve correlação positiva com os micronutrientes, e somente o Zn teve correlação positiva com a produtividade. Zn e Mn obtiveram semivariogramas cruzados que explicaram os mapas observados, enquanto o Fe obteve tendência contrária à produtividade da macadâmia.

Palavras-chave: Macadamia integrifolia, variabilidade espacial, geoestatística, nutrição de plantas 


\section{INTRODUCTION}

Macadamia (Macadamia integrifolia Maiden and Betche) is a fruit tree that belongs to the Proteaceae family and is indigenous to Australia. Plants of the Macadamia genus have good development in tropical and sub-tropical climates; this genus comprises four species, but Macadamia integrifolia is the only commercially planted species (Schneider et al., 2012). Macadamia nut has high international commercial value and good acceptance by consumers; thus, most nuts produced in Brazil is intended for export. Brazil is among the countries with higher potential for plantation and production of macadamia nuts (Rodrigues et al., 2015).

Floral abortion is one of the main problems that contribute to yield reduction, which may be correlated with the plants' nutritional imbalance (Perdoná et al., 2014). Organic matter has practically all the essential elements required by the plant, especially micronutrients (Oliveira et al., 2016), which affect plant development and the quality of the nuts produced (Huichun et al., 2015).

Brazilian soils present, in general, acidity and low fertility and organic matter content, which may limit productions due to nutritional deficiencies (Melo et al., 2015). In addition, the high nutritional requirements of macadamia plants show the importance of studies that indicate more efficient ways of fertility management for macadamia nut plantations.

Geostatistical studies using semivariograms have shown spatial dependence of soil micronutrients. Kriging is an adequate method to evaluate spatial distribution of the nutrients through mapping, as used by Gontijo et al. (2012).

The objective of this study was to evaluate the spatial variability of soil micronutrients ( $\mathrm{Fe}, \mathrm{Cu}, \mathrm{Mn}$, and $\mathrm{Zn}$ ) and organic matter, and their spatial correlation with macadamia nut yield in an Oxisol.

\section{Material ANd Methods}

The experiment was conducted in a 20-year-old plantation of macadamia plants of the HAES344 variety, in São Mateus, ES, Brazil. The trees had been planted with spacing of $8.0 \times$ $5.0 \mathrm{~m}$ (250 plants $\left.\mathrm{ha}^{-1}\right)$ under a micro-sprinkler irrigation system. The plantation area was at the UTM coordinates (24S) $388.106 .00 \mathrm{~m} \mathrm{E}, 7.934 .570 .38 \mathrm{~m} \mathrm{~S}$, at an altitude of 86 $\mathrm{m}$, and had a $4 \%$ mean slope. The soil was classified as Oxisol, which is common in the Coastal Tableland region of northern Espírito Santo. The climate of the region is Aw, tropical humid climate, with dry winter and rainy summer, according to the Köppen classification. The mean annual rainfall is $1.200 \mathrm{~mm}$, concentrated in November and January. The annual mean temperature is $23^{\circ} \mathrm{C}$, with maximum of $29^{\circ} \mathrm{C}$ and minimum of $18^{\circ} \mathrm{C}$ (Alvares et al., 2013).

The macadamia plantation was intercropped with Coffea canephora plants in alternated rows with spacing of $4.0 \times$ $2.0 \mathrm{~m}$. Soil acidity was corrected using $3.000 \mathrm{~kg}$ of dolomitic limestone (total neutralizing power of $85 \%$ ), and localized fertilization was performed before planting, using $300 \mathrm{~g}$ of simple superphosphate. In the first year, $30 \mathrm{~g}$ of urea per plant were applied during 60 days; and in the second year, $200 \mathrm{~g}$ of NPK (25-05-20) were applied per plant during 60 days between
August and March. The macadamia plants continued to receive fertilization as in the second year up to the eighth year. In the ninth year, coffee plants were removed and macadamia plants were fertilized annually (between September and March) with $150 \mathrm{~kg}$ of $\mathrm{N}, 80 \mathrm{~kg}$ of $\mathrm{P}_{2} \mathrm{O}_{5}$, and $160 \mathrm{~kg}$ of $\mathrm{K}_{2} 0$. Liming was performed annually in May with $2.000 \mathrm{~kg}$ of dolomitic limestone (total neutralizing power of $85 \%$ ).

A 100-point grid comprising an area of $144 \times 140 \mathrm{~m}$ $\left(20.160 \mathrm{~m}^{2}\right)$ was used, with a minimum distance between points of $5 \mathrm{~m}$ (Figure 1). The area was georeferenced using a pair of geodesic receptors (Spectra Precision ProMark 220). The coordinates were established and the data were processed by the Brazilian Network for Continuous Monitoring of the Brazilian Institute of Geography and Statistics, with precision of $10 \mathrm{~mm}+1 \mathrm{ppm}$. Four soil sub-samples of the $0-0.20 \mathrm{~m}$ layer were collected in each sampling point in the area, under the macadamia canopy projection, using a probe-like soil sampler, making a composite sample for chemical analysis of micronutrients ( $\mathrm{Fe}, \mathrm{Cu}, \mathrm{Mn}$ and $\mathrm{Zn}$ ) and organic matter, according to EMBRAPA (2017).

Macadamia fruits were harvested from February to June 2015 by collecting the fruits under the canopy projection, which was delimited by the division of the distance between plants. The macadamia nuts were collected manually after they dropped from the trees in four harvests, and the yield of each plant was determined by weighing them, considering the economically viable fruits. Economically unviable macadamia fruits and carpels were discarded, which represented 35\% of the production; therefore, $65 \%$ of the production was considered for evaluation. The yield obtained in $\mathrm{kg}$ per plant was transformed into $\mathrm{Mg} \mathrm{ha}^{-1}$.

An exploratory analysis of data was performed through descriptive statistics, obtaining the following parameters: arithmetic mean, median, standard deviation, sample variation, maximum and minimum values, coefficient of variation, coefficient of asymmetry and kurtoses. The frequency distribution of the data was analyzed to verify their normal distributions, using the Shapiro-Wilk test at $\mathrm{p} \leq 0.05$ probability and the Assistat 7.7 Beta program (Silva \& Azevedo, 2016).

Geostatistical analysis was used to define the spatial variability model of the evaluated soil attributes by generating semivariograms and mapping each chemical attribute through ordinary kriging. The spatial dependence was analyzed by calculating the sample semivariances, using the GS+ 7

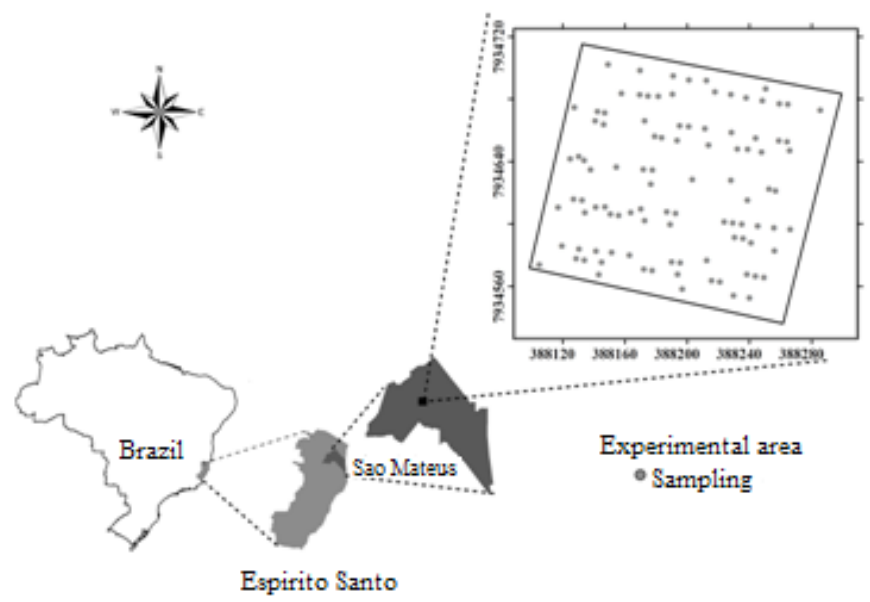

Figure 1. Sketch of the experimental area 
program (Gamma Design Software, 2004) and following the mathematical expression described by Vieira et al. (2000), as showed in Eq. 1:

$$
\hat{y}(h)=\frac{\sum_{i=1}^{n(h)}[z(x i+h)-z(x i)]^{2}}{2 n(h)}
$$

where:

$\mathrm{y}(\mathrm{h})$ - semivariance;

$\mathrm{n}(\mathrm{h})$ - number of sample pairs $[\mathrm{z}(\mathrm{xi}) ; \mathrm{z}(\mathrm{xi}+\mathrm{h})]$ separated by the vector $h$; and,

$\mathrm{z}(\mathrm{xi})$ and $\mathrm{z}(\mathrm{xi}+\mathrm{h})$ - numerical values found for the attribute analyzed, for two points $\mathrm{xi}$ and $\mathrm{xi}+\mathrm{h}$ separated by the vector $\mathrm{h}$.

The nugget effect (Co) is a parameter of the semivariogram that shows the non-explained variability, which may occur due to measurement errors or non-detected variation by the sampling scale. The structural component (C) corresponds to the difference between the sill and the nugget effect and represents the spatially structured semivariance (Cambardella et al., 1994). The nugget effect was expressed in relation to the sill to simplify the comparison of the spatial dependence degree of the studied variables. The spatial dependence ratio was calculated as the proportion (percentage) of the nugget effect in relation to the sill (Eq. 2), which, according to Cambardella et al. (1994), can be classified as: (a) strong spatial dependence, $<25 \%$; (b) moderate spatial dependence, 25 to $75 \%$; and (c) weak spatial dependence, $>75 \%$.

$$
\mathrm{DD}=\frac{\mathrm{C}_{\mathrm{o}}}{\mathrm{C}_{\mathrm{o}}+\mathrm{C}} 100
$$

where:

DD - spatial dependence degree;

$\mathrm{C}_{\mathrm{o}}$ - nugget effect; and,

$\mathrm{C}_{\mathrm{o}}+\mathrm{C}-$ sill.

Pearson's correlation was used to perform simple linear correlations for the combinations - two by two - between yield and soil attributes, using the Action 3 program.

\section{Results AND Discussion}

The results for $\mathrm{Cu}, \mathrm{Zn}, \mathrm{OM}$ and yield were close to the mean and median, showing symmetric distributions. All other variables showed some distance to the mean and median (Table 1), indicating asymmetric distributions, with central measure tendencies presenting atypical values. However, $\mathrm{Zn}, \mathrm{OM}$ and yield showed symmetrical data when tested by the ShapiroWilk test at $\mathrm{p} \leq 0.05$.

Data normality does not constitute a requisite in geostatistics. The fact that some variables do not follow a normal distribution has no influence on the analysis. This denotes the importance of using geostatistics to represent variability. The use of geostatistics is recommended when considering the soil as heterogeneous, and the variables as independent of each other and not arbitrary, representing data with normal distribution. According to the preliminary exploratory analysis, it was assumed that distributions were symmetric enough and long tailed. It was also assumed a nonoccurrence of proportional effect, enabling the development of well-defined semivariograms.

According to the classification of Warrick \& Nielsen (1980), coefficients of variation (CV) were regular $(12<\mathrm{CV}<62 \%)$ for chemical attributes and nut yield. Gontijo et al. (2012) evaluated the same soil type and found regular $\mathrm{CV}$ for $\mathrm{Fe}, \mathrm{Cu}$, $\mathrm{Mn}, \mathrm{Zn}$ and $\mathrm{OM}$.

The lower the CV, the homogeneous the data set. Consequently, the low $\mathrm{CV}$ found for $\mathrm{OM}$ is explained by the normality found among its data through the Shapiro-Wilk test. The high CV values found for some attributes indicate high heterogeneity close to the mean, as in the case of available $\mathrm{Fe}$ $(\mathrm{CV}=48 \%)$. This may be explained by the heterogeneity of the soil use and fertility.

The $\mathrm{C} /(\mathrm{Co}+\mathrm{C})$ ratio for $\mathrm{Zn}, \mathrm{Mn}, \mathrm{MO}$ and yield (Table 2) showed these variables with moderate spatial dependence $(25 \%<\mathrm{GD}<75 \%)$; while $\mathrm{Fe}$ and $\mathrm{Cu}$ showed strong spatial dependence $(<25 \%)$, according to classification suggested by Cambardella et al. (1994). Similar results were found by Chig et al. (2016) for Fe and Mn in a swampy environment.

Values of the range of the semivariograms are considerably important in determining the spatial dependence limit; thus, samples that show distances between them higher than the value of the range have random distributions and are independent from each other, with no restrictions for the use of classic statistics (Chaves \& Farias, 2009).

The range values varied from 34.4 to $130 \mathrm{~m}$ for $\mathrm{Fe}$ and $\mathrm{OM}$, respectively. Similar results were found by Zanão Junior et al. (2010) and Lima et al. (2013) in a Red-Yellow Acrisol of clayey texture. Fe, $\mathrm{Zn}, \mathrm{Mn}$ and yield had range from 30 to $70 \mathrm{~m}$. Attributes with higher range of spatial dependence tend to be more spatially homogeneous, as seen in the map for OM

\begin{tabular}{|c|c|c|c|c|c|c|}
\hline \multirow{2}{*}{ Descriptive statistics } & $\mathrm{Fe}$ & Cu & $\mathrm{Zn}$ & $\mathrm{Mn}$ & \multirow{2}{*}{$\begin{array}{c}\text { OM } \\
\left(\operatorname{dag} \mathrm{dm}^{-3}\right)\end{array}$} & \multirow{2}{*}{$\begin{array}{c}\text { Yield } \\
\left(\mathrm{Mg} \mathrm{ha}^{-1}\right)\end{array}$} \\
\hline & \multicolumn{4}{|c|}{$\left(\mathrm{mg} \mathrm{dm}^{-3}\right)$} & & \\
\hline Mean & 80.8 & 8.48 & 12.24 & 18.1 & 2.03 & 5.2 \\
\hline Median & 66.4 & 8 & 12.8 & 17.2 & 2 & 5.1 \\
\hline Standard error & 38.8 & 2.7 & 4.3 & 8.5 & 0.3 & 1.1 \\
\hline Sample variance & 1506.5 & 7.3 & 18.5 & 72.3 & 0.1 & 1.2 \\
\hline Minimum & 35.5 & 2.2 & 3.1 & 3.6 & 1.2 & 2.5 \\
\hline Maximum & 220 & 16.1 & 25.2 & 42.6 & 2.8 & 8.3 \\
\hline Coefficient of variation (\%) & 48 & 31.9 & 35.1 & 47 & 16.1 & 21.1 \\
\hline Coefficient of asymmetry & 1.631 & 0.682 & 0.264 & 0.737 & -0.127 & 0.130 \\
\hline Coefficient of kurtoses & 2.186 & 0.559 & -0.188 & 0.285 & 0 & 0.296 \\
\hline Shapiro-Wilk ( $p$-value) & 0 & 0.00439 & $0.35858^{*}$ & 0.00201 & $0.40465^{\star}$ & $0.91370^{*}$ \\
\hline
\end{tabular}

Table 1. Descriptive statistics of data of soil micronutrients, organic matter and macadamia nut yield, obtained from 100 samples

${ }^{*}$ Normal distribution by the Shapiro-Wilk test at $\mathrm{p} \leq 0.05$ 
Table 2. Models and parameters estimated by experimental semivariograms for micronutrients, organic matter and macadamia nut yield

\begin{tabular}{|lcccccc|}
\hline \multicolumn{1}{c}{ Parameters } & Fe & Cu & Zn & Mn & OM & Yield \\
\hline Model & SPH & SPH & SPH & SPH & SPH & SPH \\
Nugget effect (Co) & 1 & 0.54 & 9.32 & 27.3 & 0.0367 & 0.665 \\
Sill (Co + C) & 1103 & 7.89 & 19.04 & 85 & 0.1354 & 1.331 \\
DD $(\%)$ & 0.1 & 6.8 & 48.9 & 32.1 & 27.1 & 49.96 \\
R & 0.974 & 1 & 0.795 & 0.952 & 0.970 & 0.880 \\
SSR & 24254 & $1.210^{-3}$ & 23.8 & 119 & $2.710^{-4}$ & 0.0428 \\
CVRC (\%) & 98.8 & 31.7 & 81.3 & 87.4 & 91.5 & 55.7 \\
A (m) & 34.4 & 14.6 & 55.9 & 64 & 133.3 & 40.4 \\
\hline
\end{tabular}

SPH - Spherical model; DD - Degree of spatial dependence; $\mathrm{R}^{2}$ - Coefficient of determination; SSR - Sum of squared residues; CVRC - Cross-validation regression coefficient

(Figure 2). Contrastingly, low range values may affect negatively the quality of the estimations, since few points are used to perform the interpolation (Lima et al., 2013).

The nutrients presented $\mathrm{R}^{2}$ higher than 0.795 , i.e., more than $79.5 \%$ of the variation of estimated semivariance values are explained by the models, denoting that the semivariogram models satisfied the requirements of spatial interpolation. Similar results were reported by Santos et al. (2014), who evaluated Conilon coffee plantations in an Oxisol and found a high fitting degree of the dependent variable by independent variables.

Spatial dependence was found for all evaluated attributes, expressed by means of the fitting to semivariogram models (Figure 2). The soil chemical attributes and macadamia nut yield fitted to the spherical model (Table 2 and Figure 2). Similarly, Marques Júnior et al. (2015) found predominantly spherical mathematical model in soil science studies.

The cross-validation regression coefficient (CVRC) varied from 55.7 to $98.8 \%$ for the macadamia nut yield and $\mathrm{Fe}$, respectively. In this analysis, after obtaining the variogram model, each original value was removed from the spatial domain and, using the other ones, a new value was estimated for that point. Thus, a graphic showing the relation between real and estimated values was developed. Cross validation does not prove

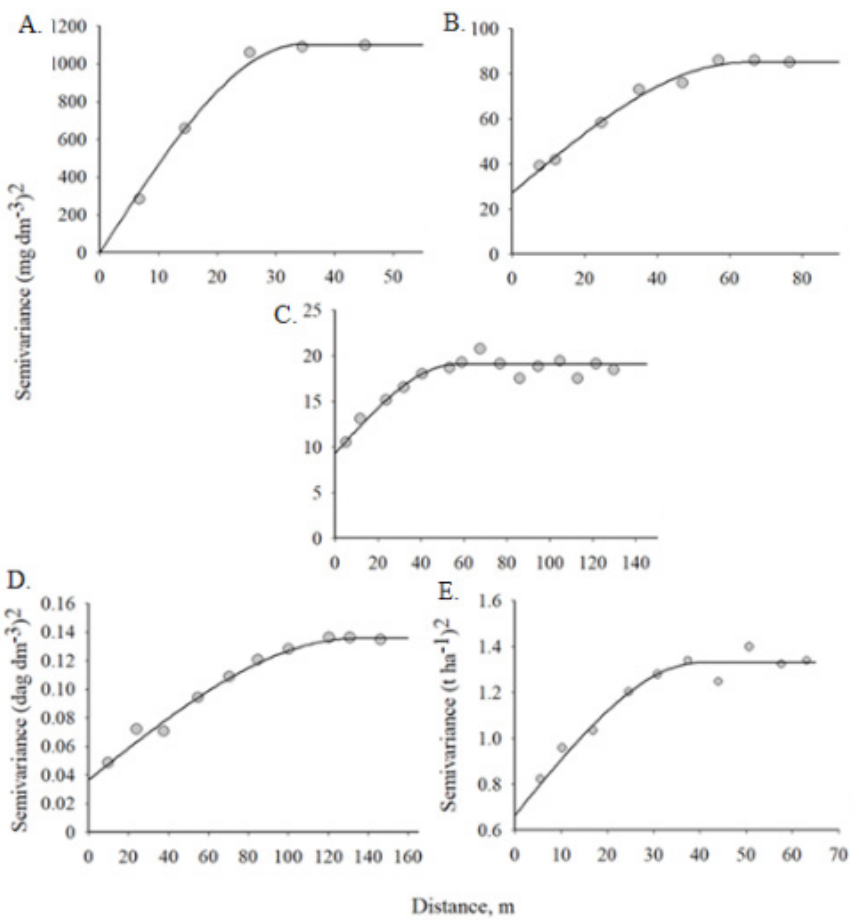

Figure 2. Semivariograms models for Fe (A), Mn (B), $\mathrm{Zn}(\mathrm{C})$, organic matter (D) and macadamia nut yield (E) that the selected model is the most correct, but rather that such model is not entirely incorrect. The CVRC for Fe shows that its estimate in the soil, using kriging, has a lower error and, therefore, it is more reliable (Landim, 2007). The cross-validation method measures the uncertainty of data prediction, i.e., it verifies the reliability of the variogram model, which will reflect in the interpolation of the data and, consequently, in the mapping by kriging. Faraco et al. (2008) evaluated diverse criteria for soil attributes validation and concluded that cross validation was an adequate method to select the best fit.

The maps in Figure 3 show a general tendency of higher iron concentrations at northeast and zinc and manganese concentrations in the central area.

According to the fertility classification proposed by Prezotti et al. (2007), all micronutrient contents in the area are classified as high - Fe $\left(>45.0 \mathrm{mg} \mathrm{dm}^{-3}\right), \mathrm{Cu}\left(>1.8 \mathrm{mg} \mathrm{dm}^{-3}\right), \mathrm{Zn}$ $\left(>2.2 \mathrm{mg} \mathrm{dm}^{-3}\right)$, and $\mathrm{Mn}\left(>12 \mathrm{mg} \mathrm{dm}^{-3}\right)$ - and OM contents are classified as average (1.5-3.0 dag $\left.\mathrm{dm}^{-3}\right)$.

Regions with spots of high nut yield are in areas with high $\mathrm{Zn}$ and Mn contents (Figure 3). The highest macadamia nut yield found (5.1 Mg ha-1; $20.4 \mathrm{~kg} \mathrm{plants}^{-1}$ ) was higher than that found by Perdoná et al. (2012) for the same cultivar $\left(10.7 \mathrm{~kg}\right.$ plant $\left.{ }^{-1}\right)$.

Micronutrients and OM showed close relation (Figure 3). The available Fe increased as the $\mathrm{OM}$ increased, confirming the results found by Huichun et al. (2015). This may be due to the OM decomposition, complexation and chelatization, the dissolution of the organic and humic acids produced during the decomposition process, and the transformation of the soil active OM, which increase Fe availability (Bernardi et al., 2015). The chelated micronutrient becomes more soluble and its availability increases in the soil solution. $\mathrm{Zn}$ presented similar behavior; however, in areas with high $\mathrm{OM}$ concentrations (> $2.20 \mathrm{dag} \mathrm{dm}^{-3}$ ), $\mathrm{Zn}$ concentrations were regular ( 1.0 to $2.2 \mathrm{mg} \mathrm{dm}^{-3}$ ).

The differences found indicate that the use of different doses of soil amendments, sub-dividing the area into management units, optimizes the use of agricultural inputs and, consequently, increases the crop yield. The definition of soil management units, which represent homogeneous regions regarding soil attributes that affect plant development, is one of the most challenging stages in precision agriculture (Santos et al., 2012). The developed maps denoted, in general, favorable conditions for plant development. Therefore, soil fertilization and tillage affect the spatial variability of soil nutrients.

The yield map showed higher yields in areas with high Zn concentrations, as confirmed by their positive correlation (Table 3) and results found by Gontijo et al. (2012). 

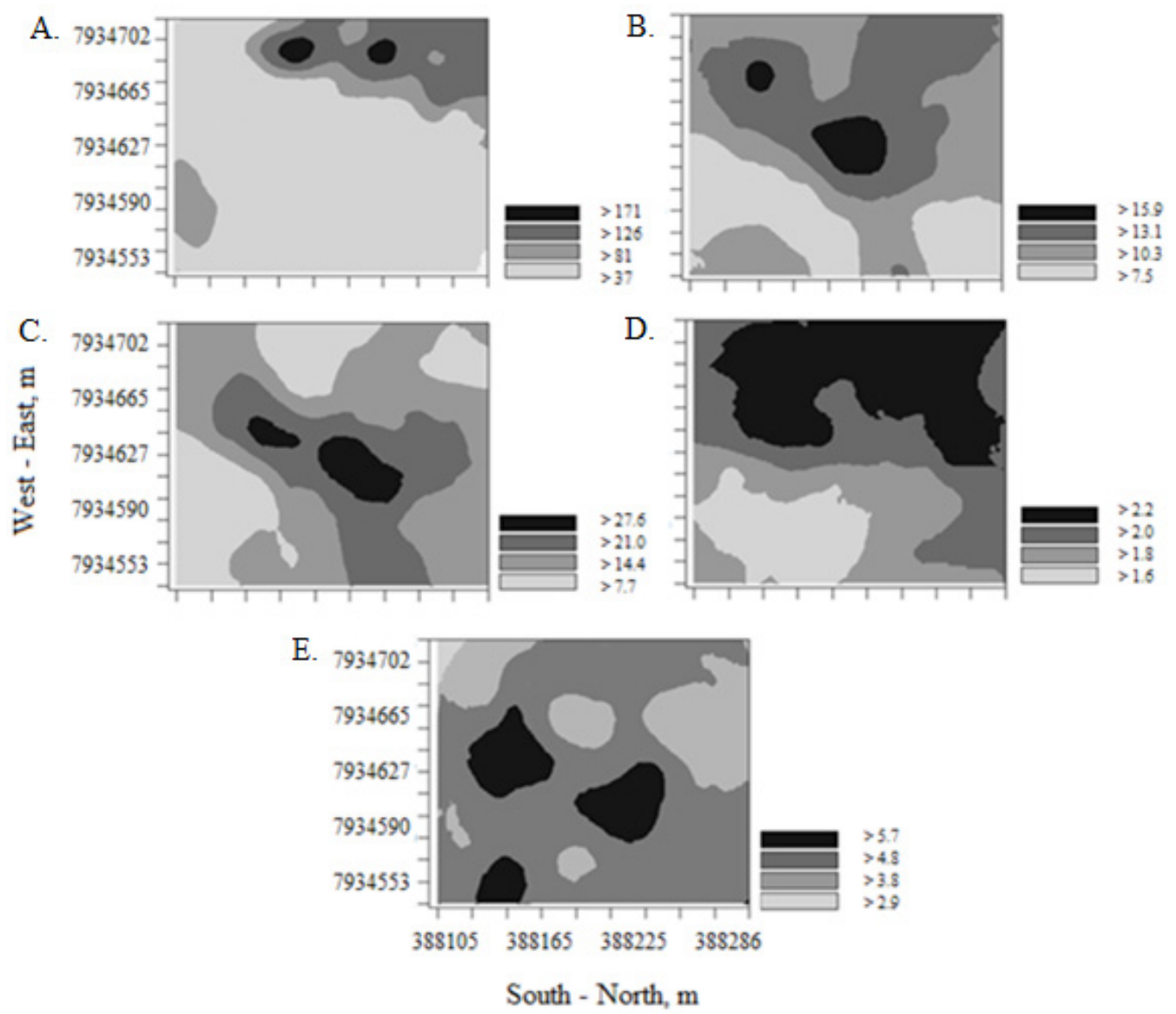

Figure 3. Isoline maps for $\mathrm{Fe}(\mathrm{A}), \mathrm{Zn}(\mathrm{B}), \mathrm{Mn}(\mathrm{C})$, organic matter (D) and macadamia nut yield (E)

Table 3. Simple linear correlation between macadamia nut yield and soil chemical attributes in an Oxisol

\begin{tabular}{|c|c|c|c|c|c|c|}
\hline $\begin{array}{c}\text { Soil } \\
\text { attributes }\end{array}$ & Yield & $\mathrm{Fe}$ & Cu & $\mathrm{Zn}$ & Mn & OM \\
\hline Yield & 1 & -0.0871 & 0.00785 & $0.201^{*}$ & 0.17 & 0.0139 \\
\hline $\mathrm{Fe}$ & & 1 & 0.0941 & 0.00984 & $-0.199 *$ & $0.402^{* *}$ \\
\hline $\mathrm{Cu}$ & & & 1 & $0.288^{* *}$ & $0.208^{*}$ & $0.293^{* *}$ \\
\hline $\mathrm{Zn}$ & & & & 1 & $0.635^{\star \star}$ & $0.363^{\star \star}$ \\
\hline $\mathrm{Mn}$ & & & & & 1 & $0.222^{*}$ \\
\hline OM & & & & & & 1 \\
\hline
\end{tabular}

The linear correlation between macadamia nut yield and $\mathrm{Zn}$ concentration was weak, according to Dancey \& Reidy (2005). The OM correlated positively with all evaluated nutrients; this attribute is an indicator of soil quality in agricultural areas and an important component of the soil, which is responsible for soil structuration and the supply of macro and micronutrients (Zanão Júnior et al., 2010). The presence of OM in the soil is associated with the availability, quantity and retention of some micronutrients in the soil, such as $\mathrm{Fe}, \mathrm{Cu}, \mathrm{Mn}$ and $\mathrm{Zn}$, since these micronutrients are released with the decomposition of OM (Silveira \& Cunha, 2002).

\section{Conclusions}

1. Spatial dependence was found for all evaluated soil chemical attributes, except for $\mathrm{Cu}$, with strong and moderate degrees of spatial dependence.

2. Higher range of spatial dependence was found for organic matter $(133.3 \mathrm{~m})$, and lower range for iron $(34.4 \mathrm{~m})$.
3. The contrasts in the $\mathrm{Zn}$ and $\mathrm{Mn}$ maps showed the correlation of these nutrients with yield, which was not found for Fe.

4. The organic matter had significant correlation with all micronutrients, and $\mathrm{Zn}$ had significant correlation with yield.

\section{ACKNOWLedgments}

The authors thank the farmer Mr. Eliseu Bonomo, for allowing the implementation of the experimental area and to the Agronomic Engineer Ítalo Bonomo, for the technical advisory during the research. To FAPES for the financial support.

\section{Literatura Cited}

Alvares, C. A.; Stape, J. L.; Sentelhas, P. C.; Gonçalves, J. L. M.; Sparovek, G. Köppen's climate classification map for Brazil. Meteorologische Zeitschrift, v.22, p.711-728, 2013. https://doi. org/10.1127/0941-2948/2013/0507

Bernardi, J. V. E.; Neira, M. P.; Manzatto, A. G.; Holanda, I. B. B. de; Almeida, R. de; Bastos, W. R.; Dórea, J. G.; Landim, P. B.; Vieira, L. C. G. Aplicação da análise geoestatística para modelagem espacial do mercúrio e matéria orgânica em solos florestais na Amazônia Ocidental. Journal of Social, Technological and Environmental Science, v.4, p.31-46, 2015. https://doi.org/10.21664/22388869.2015v4i3.p31-46

Cambardella, C. A.; Moorman, T. B.; Novak, J. M.; Parkin, T. B.; Karlen, D. L.; Turco, R. F.; Konopka, A. E. Field-scale variability of soil properties in central Iowa soils. Soil Science Society of America Journal, v.58, p.1501-1511, 1994. https://doi.org/10.2136/ sssaj1994.03615995005800050033x 
Chaves, L. H. G.; Farias, C. H. de A. Variabilidade espacial de cobre e manganês em Argissolo sob cultivo de cana-de-açúcar. Revista Ciência Agronômica, v.40, p.211-218, 2009.

Chig, L. A.; Couto, E. G.; Beirigo, R. M.; Lobato, L. A. de O.; Novaes Filho, J. P. Distribuição espacial de ferro e manganês trocáveis em solos do pantanal. Ambiência v.12, p.233-249, 2016. https://doi. org/10.5935/ambiencia.2016.01.14

Dancey, C.; Reidy, J. Estatística sem matemática para psicologia: Usando SPSS para Windows. 4.ed. Porto Alegre: Artmed, 2006. $608 \mathrm{p}$.

EMBRAPA - Empresa Brasileira de Pesquisa Agropecuária. Manual de métodos de análise de solo. 3.ed. Brasília: Embrapa Informação Tecnológica, 2017. 573p.

Faraco, M. A.; Uribe-Opazo, M. A.; Silva, E. A. A. da; Johann, J. A.; Borssoi, J. A. Seleção de modelos de variabilidade espacial para elaboração de mapas temáticos de atributos físicos do solo e produtividade da soja. Revista Brasileira de Ciência do Solo, v.32, p.463-476, 2008. https://doi.org/10.1590/S010006832008000200001

Gamma Design Software. Geoestatistics for the environmental sciences. Version 7.0. Michigan: Gamma Design Software, 2004. CD-Rom

Gontijo, I.; Nicole, L. R.; Partelli, F. L.; Bonomo, R.; Santos, E. O. de J. Variabilidade e correlação espacial de micronutrientes e matéria orgânica do solo com a produtividade da pimenta-do-reino. Revista Brasileira de Ciência do Solo, v.36, p.1093-1102, 2012. https://doi.org/10.1590/S0100-06832012000400004

Huichun, Y.; Chongyang, S.; Yuanfang, H; Wenjiang, H.; Shiwen, Z.; Xiaohong, J. Spatial variability of available soil microelements in an ecological functional zone of Beijing. Environmental Monitoring and Assessment, v.187, p.1-12, 2015. https://doi. org/10.1007/s10661-014-4230-7

Landim, P. M. B. Sobre geoestatística e mapas. Terra Didática, v.2, p.19-33, 2007. https://doi.org/10.20396/td.v2i1.8637463

Lima, J. S. S.; Silva, S. A.; Silva, J. M. Variabilidade espacial de atributos químicos de um Latossolo Vermelho-Amarelo cultivado em plantio direto. Revista Ciência Agronômica, v.44, p.16-23, 2013. https://doi.org/10.1590/S1806-66902013000100003

Marques Júnior, J. M.; Alleoni, L. R. F.; Teixeira, D. de D.; Siqueira, D. S.; Pereira, G. T. Sampling planning of micronutrients and aluminium of the soils of São Paulo, Brazil. Geoderma Regional, v.4, p.91-99, 2015. https://doi.org/10.1016/j.geodrs.2014.12.004

Melo, C. A. D.; Guimarães, F. A. R.; Gonçalves, V. A.; Benevenute, S. da S.; Ferreira, G. L.; Ferreira, L. R.; Ferreira, F. A. Acúmulo de macronutrientes por plantas daninhas e de milho cultivadas em convivência em solo com diferentes manejos de fertilidade. Semina: Ciência Agrárias, v.36, p.669-682, 2015. https://doi. org/10.5433/1679-0359.2015v36n2p669

Oliveira, W. C. de; Nascimento, M. H. do; Santos, A. R. dos; Souza, L. da S. Efeito da matéria orgânica no crescimento de plantas de girassol (Helianthus annuus L.) cultivadas em Latossolo Amarelo. Revista Biociências, v.22, p.1-9, 2016.
Perdoná, M. J.; Martin, A. V.; Suguino, E.; Soratto, R. P. Crescimento e produtividade de nogueira-macadâmia em consórcio com cafeeiro arábica irrigado. Pesquisa Agropecuária Brasileira, v.47, n.11, p.1613-1620, 2012. https://doi.org/10.1590/S0100204X2012001100008

Perdoná, M. J.; Suguino, E.; Martins, A. N.; Sorattos, R. P. Abortamento de frutos da nogueira macadâmia sob influência da adubação mineral. Revista Ceres, v.61, p.392-398, 2014. https://doi. org/10.1590/S0034-737X2014000300014

Prezotti, L. C.; Gomes, J. A.; Dadalto, G. G.; Oliveira, J. A. Manual de recomendação de calagem e adubação para o Estado do Espírito Santo: 5. aproximação. Vitória: SEEA/INCAPER/CEDAGRO, 2007. 305p.

Rodrigues, D. A.; Freitas, R. R.; Lira, T. S.; Xavier, T. P. Utilização dos resíduos provenientes do beneficiamento da noz macadâmia: Uma revisão sistemática. Brazilian Journal of Production Engineering, v.1, p.1-13, 2015.

Santos, E. O. de J.; Gontijo, I.; Nicole, L. R. Variabilidade espacial de cálcio, magnésio, fósforo, potássio no solo e produtividade da pimenta-do-reino. Revista Brasileira de Engenharia Agrícola e Ambiental, v.16, p.1062-1068, 2012. https://doi.org/10.1590/ S1415-43662012001000005

Santos, E. O. de J.; Gontijo, I.; Silva, M. B. da. Planejamento amostral dos teores de $\mathrm{Cu}, \mathrm{Fe}, \mathrm{Mn}, \mathrm{Zn}$ e $\mathrm{Na}$ em Latossolo cultivado com café conilon. Revista de Ciências Agroveterinárias, v.13, p.318326, 2014.

Schneider, L. M.; Rolim, G. de S.; Sobierajski, G. da R.; PrelaPantano, A.; Perdoná, M. J. Zoneamento agroclimático de nogueira-macadâmia para o brasil. Revista Brasileira de Fruticultura, v.34, p.515-524, 2012. https://doi.org/10.1590/ S0100-29452012000200025

Silva, F. de A. S. e; Azevedo, C. A. V. de. The Assistat Software version 7.7 and its use in the analysis of experimental data. African Journal of Agricultural Research, v.11, p.3733-3740, 2016. https://doi. org/10.5897/AJAR2016.11522

Silveira, P. M. da; Cunha, A. A. da. Variabilidade de micronutrientes, matéria orgânica e argila de um Latossolo submetido a sistemas de preparo. Pesquisa Agropecuária Brasileira, v.37, p.1325-1332, 2002. https://doi.org/10.1590/S0100-204X2002000900017

Vieira, S. R. Geoestatística em estudos de variabilidade espacial do solo. In: Novais, R. F.; Alvarez V., V. H.; Schaefer, G. R. (eds.). Tópicos em ciência do solo. Viçosa: Sociedade Brasileira de Ciência do Solo, 2000. Cap.1, p.1-54.

Warrick, A. W.; Nielsen, D. R. Spatial variability of soil physical properties in the field. In: Hillel, D. (ed). Applications of soil physical. New York: Academic, 1980. Cap.2, p.319-344. https:// doi.org/10.1016/B978-0-12-348580-9.50018-3

Zanão Júnior, L. A.; Lana, R. M. Q.; Carvalho-Zanão, M. P.; Guimarães, E. C. Variabilidade espacial de atributos químicos em diferentes profundidades em um Latossolo em sistema de plantio direto. Revista Ceres, v.57, p.429-438, 2010. https://doi.org/10.1590/ S0034-737X2010000300021 